\title{
Donor Preferences and Charitable Giving
}

Received (in revised form): September 17, 2007

\section{Stephanie Roderick Williams}

holds a Master degree in Nonprofit Administration from the University of San Francisco and a BA in psychology from Boston College. She has worked for numerous nonprofit organizations, including the World Society for the Protection of Animals and The Marine Mammal Center, where she was the Director of Annual Giving. She now lives in Glen Ellyn, IL and works as a fundraising consultant for Catch the Science Bug Foundation.

\section{Abstract}

This study aimed to learn more of the differences that may exist between the two most powerful groups of donors today, baby boomers ( $40-58$ years old) and mature donors (59 and older), in an effort to help organizations improve fundraising efforts. Questions about the importance of organizational efficiency, program outcomes, and the desire for information were explored. This study entailed the administration of a mail survey of 2,000 donors. ${ }^{1}$

Statistically significant differences existed between the following age groups:

- baby boomers and mature donors, where baby boomers valued information more than mature donors;

- young donors (aged 18-39) and baby boomers, where young donors valued efficiency less; and

- young donors and mature donors, where young donors valued efficiency

Author's Contact Address:

Stephanie Roderick Williams

394 Carleton Ave.

Glen Ellyn

IL 60137, USA

Phone: +1630 4749832

Fax: +1 3123778299

E-mail: stephanieroderick@hotmail.com less and outcomes and information more than mature donors.

This study confirmed that a majority of donors value organizational efficiency and outcomes and that most donors seek information when making a decision to give. It also revealed significant differences between age groups that may help fundraisers and policy makers improve their understanding of donor preferences and charitable giving. International Journal of Educational Advancement (2007) 7, 176-189. doi:10.1057/palgrave.ijea.2150060

Keywords: development, fundraising, donor preferences, donor cultivation, baby boomer, efficiency

\section{Introduction}

During the next 50 years, an estimated \$41-\$136 trillion will transpire from the mature generation (those born before 1945) to the baby boomer generation (those born between 1946 and 1964) (Weiss, 2003). By 2030, baby boomers will double the current senior population (Nayyar, 2003). 
Because they are exceptionally large in number, making them an anomaly, boomers have been taught from birth that they are special (Nichols, 1996; Smith and Clurman, 1997, p. 46). The values that shaped this generation include a strong sense of self, independence, and change. As a result, choice and control are very important to baby boomers (Haynes, 2004; see also Smith and Clurman, 1997, Chapter 3). Boomers prefer supporting causes with quantifiable results, and they have a strong desire to make things happen with their money (Nichols, 1989). They also tend to view their contributions as investments and thus demand some measurable return on their support (Hart, 1999).

Factors that affect giving are complex and varied. Organizational outcomes and efficiency are known to be important factors, however, and their roles are being studied and measured with increasing interest.

Recent studies have shown that people are looking for more information about the activities of charities (Princeton Survey Research Associates, Inc., 2001; Sargeant and Lee, 2002) and that disclosure of financial information increases association with higher subsequent donations (Parsons, 2001). Studies have also shown that donors have concerns about whether their donation will be used efficiently (Hall and Parmegiani, 1998; Hall et al., 1998, 2001; Hall and Febbraro, 1999; Sargeant and Lee, 2002).

\section{Purpose of this study}

This research seeks to determine whether baby boomers, due to their unique characteristics, are more likely to value organizational outcomes, efficiency, and information as factors that affect their giving. Specifically, the hypothesis states that donors of the baby boomer generation (40-58 years old) will be more likely than older, more mature donors to value organizational outcomes, efficiency, and information when making a charitable gift.

\section{Literature Review}

The literature is clear on the fact that donors have serious concerns about efficiency and outcomes and that donors want charities to disclose more information to help them make sound giving decisions (Drtina, 1984; Hyndman, 1991; Cherny et al., 1992, Chapter 1; Khumawala and Gordon, 1997; Hall and Parmegiani, 1998; Hall et al., 1998; Hall and Febbraro, 1999; Princeton Survey Research Associates, Inc., 2001; Maryland Association of Nonprofit Organizations, 2002; Sargeant and Lee, 2002).

\section{The importance of organizational efficiency}

Individuals from Princeton Survey Research Associates' 2001 survey cited financial information as the most important piece of information that donors need. Financial information is often used to determine an organization's level of efficiency: the amount spent on programs versus fundraising and administration. Hyndman (1991) and Khumawala and Gordon (1997) report that donors' principal financial concern is the percent of expenses dedicated to programs. Anthony (1983, p. 34), Cherny et al. (1992, Chapter 9), and Drtina (1984, Chapter 7), agree that when potential 
donors examine accounting measures, they are most interested in organizational efficiency and effectiveness. Marylanders report that the organization's mission and efficiency (described as not spending excessive amounts on fundraising and administration) are the most important factors when making a decision to give (The Maryland Association of Nonprofit Organizations, 2002).

Various studies have also demonstrated that donors are concerned about how their gift will be used (Hall et al., 1998; Hall and Febbraro, 1999). Hall and Febbraro (1999) documented that eight out of ten Canadian donors are concerned about the use of donated dollars or fundraising practices. Sargeant and Lee's survey of 1,000 individuals in the United Kingdom revealed that the public wants charities to do a better job of reporting how their gift was used (Sargeant and Lee, 2002). In contrast, one recent study interviewed major donors ${ }^{2}$ and found that the majority (18 out of 22 donors) were not interested in receiving additional data on organizational efficiency (Cunningham and Ricks, 2004). This study suggests that there may be significant differences between the needs of the general public and of major donors, who are likely to have a more intimate relationship with the charities they support and be solicited in person.

\section{The importance of program outcomes}

In addition to reporting more information about how gifts are being used, the public is also asking for more information about charities' accomplishments in carrying out their mission and the effectiveness of their programs (Princeton Survey Research Associates, Inc., 2001). Hyndman (1991) finds that donors, charity officials, and auditors working in the third sector list output measures as one of the most important factors necessary for making a contribution decision.

\section{Methodology}

Donors were selected from The Marine Mammal Center, an animal welfare/ environmental nonprofit organization with 30,000 supporting members. Two thousand members (donors who made a gift of 100-499 dollars in the past 12 months) were randomly selected. Only donors who lived in California were included in the query. Donors who gave monthly donations were excluded from the query. A survey was mailed to these donors and the response rate was 38 percent. The results from 739 usable surveys were entered into an SSPS database for analysis.

Donors to The Marine Mammal Center were divided into six age groups:

1. Young Adult 1 (18-28)

2. Young Adult 2 (29-39)

3. Baby boomer $1(40-48)$

4. Baby boomer 2 (49-58)

5. Mature Adult 1 (59-69)

6. Mature Adult 2 (70 or older)

Definitions for the variables of interest included:

- Organizational outcomes: the recent and/or long-term stated accomplishments of an organization. Stated accomplishments must relate to the organization's program 
activities, which work to carry out their specific mission.

- Organizational efficiency: the percent of a charity's total spending for charitable programs, as opposed to overhead (fundraising and administrative costs).

- Desire for information: financial, outcome, or other information on a charitable organization that donors desire or actively seek when making a decision to give.

- Age: defined by one of the six different age groups noted above.

The instrumentation used to gather information was a three-page, doublesided survey containing 13 questions. The BBB Wise Giving Alliance Donor Expectations Survey (Princeton Survey Research Associates, Inc., 2001) was used to develop a portion of the survey questions.

\section{Limitations}

The research design had limitations. First, information was gathered from donors to animal welfare/ environmental organizations, and of these, donors to only one organization within this category. While many of these donors may also give to similar causes and non-similar causes, this information was not collected. Information collected on the independent variable, donors' age, was limited to set age groups. Therefore, differences that may exist within a particular age group were not evidenced. Another limitation of the design was that the survey was short. There were three dependent variables, and only four questions to capture information for each dependent variable. In-depth information was not gathered and additional questions to check the validity of each variable were not captured.

\section{Summary of Findings}

No significant differences between baby boomers and mature donors were found regarding the variables efficiency and outcomes. Statistically significant differences between baby boomers and mature donors, however, were found regarding the variable information, where baby boomers valued information more than mature donors.

Interestingly, statistically significant differences between young donors (18-39 years old) and baby boomers and young donors and mature donors were found regarding organizational efficiency. Significant differences between young donors and mature donors were also found regarding their valuation of organizational outcomes.

Among the three age groups, young donors placed the least value on organizational efficiency when making a decision to give and mature donors placed the greatest value on this variable. This result was statistically significant at the 0.000 level. The difference between young donors and baby boomers was also statistically significant at the 0.006 level, where baby boomers placed a greater value on organizational efficiency than young donors.

Conversely, young donors were more likely than baby boomers and mature donors to value an organization's program outcomes when making a decision to give. This result was almost statistically significant at the 0.061 level, with the difference between young donors and mature donors the most visible, and almost statistically significant at the 0.062 level. 
Lastly, there were also differences between age groups regarding the types of sources donors used to find information and the number of different sources used. Young donors used the internet, a charity's website, and their friends or family significantly more than baby boomers and mature donors when making a decision to give. These results were statistically significant at the $0.000,0.000$, and 0.033 gamma levels, respectively. Young donors also used more sources for information than baby boomers and mature donors; this difference was significant at the 0.000 level.

\section{Construction of scales}

The three dependent variables (efficiency, outcomes, and information) had multiple measures. Therefore, a scale was created for each variable by adding the answers to related questions together. Questions 1-4 comprised the variable efficiency. Questions 5-8 comprised the variable outcomes and questions 9, 10, and 12 comprised the variable information. A reliability coefficient was then calculated to ensure that the questions for each variable comprised a single dimension. The reliability coefficient for each of the variables was significant at the following levels:

- Efficiency $=0.557$

- Outcomes $=0.565$

- Information $=0.539$.

Data were analyzed using an analysis of variance test. The results from the analysis of variance test showed that young donors valued the efficiency rating of a charitable organization less than baby boomers and mature donors when making a decision to give and that mature donors valued an organization's efficiency rating the most. As demonstrated in Table 1, these differences were statistically significant at the 0.000 level.

Figure 1 displays the correlation between increasing age and increasing concern for organizational efficiency in a bar graph. Table 1 also shows that the differences between age groups concerning outcomes were almost statistically significant at the 0.061 level. Young donors reported valuing outcomes the most and mature donors the least. Figure 2 displays the

Table 1: Analysis of variance for three dependent variables

\begin{tabular}{lrrrr}
\hline & $\begin{array}{c}\text { Young } \\
\text { donors }\end{array}$ & $\begin{array}{l}\text { Baby } \\
\text { boomers }\end{array}$ & $\begin{array}{l}\text { Mature } \\
\text { donors }\end{array}$ & Significance \\
\hline Efficiency & 14.288 & 15.355 & 15.614 & 0.000 \\
Outcomes & 13.475 & 12.852 & 12.719 & 0.061 \\
Information & 9.441 & 9.571 & 9.499 & 0.895 \\
\hline
\end{tabular}

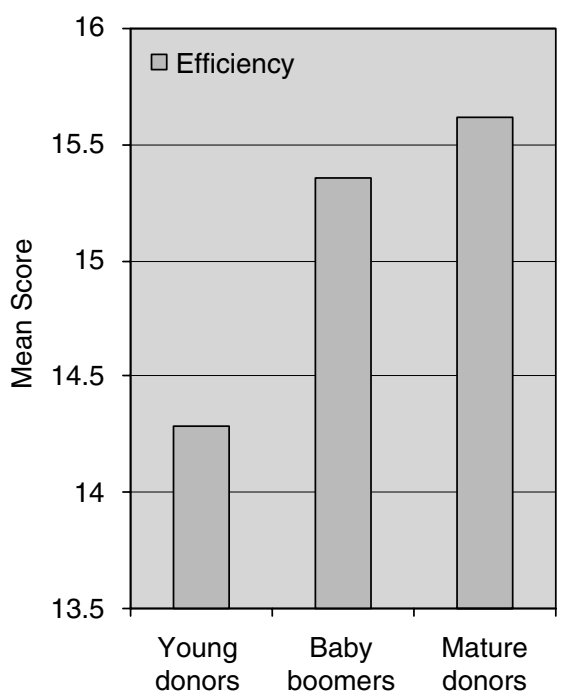

Figure 1: Analysis of variance for the variable efficiency 
correlation between increasing age and decreasing concern for outcomes in a bar graph.

As demonstrated, the analysis of variance test showed statistically significant results for the variables efficiency and outcomes; thus, a post hoc test was conducted using a Scheffe comparison test. The results from the Scheffe comparison test demonstrated that the difference between young donors and mature donors concerning efficiency was quite significant at the 0.000 level. The difference between young donors and baby boomers was also significant at the 0.006 level. The difference between baby boomers and mature donors was not statistically significant.

The results from the Scheffe comparison test also demonstrated that the difference between young donors and mature donors concerning outcomes was almost statistically significant at the 0.062 level.

There were no significant differences between age groups regarding the variable information, as it was

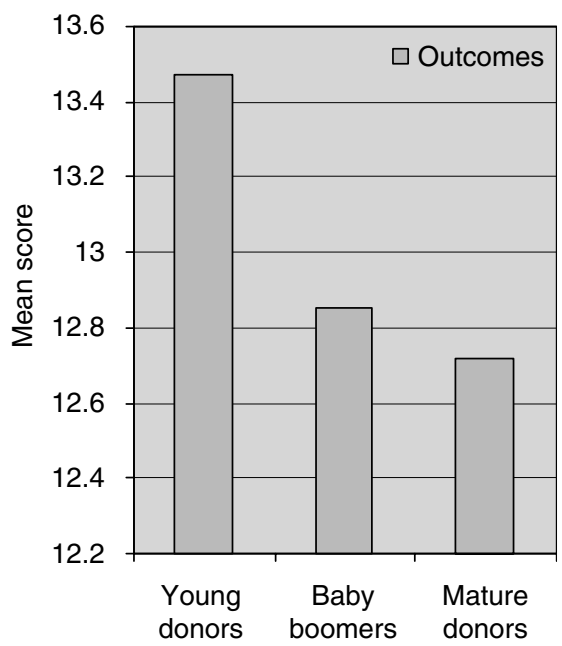

Figure 2: Analysis of variance for the variable outcomes calculated using data from questions 9,10 , and 12 . When question number 11, which asked donors to check off how many different sources of information they used to find information was treated as a separate variable, however, an analysis of variance test showed that significant differences between age groups existed at the 0.000 level.

Young donors looked at more sources of information than mature donors, and baby boomers looked at more sources than mature donors. A Scheffe comparison test showed that these results were significant at the 0.003 and 0.000 levels, respectively. The results from the Scheffe comparison test concerning efficiency, outcomes, and question 11 are displayed in Table 2.

\section{Findings question by question} Each of the survey's questions was treated as a separate measure and cross-tabulated using gamma and chi-square against the independent variable of age. Chi-square was used to show the significance of the association for the general population. Gamma was used to measure the

Table 2: Scheffe comparison test

\begin{tabular}{lcccc}
\hline & YD & BB & MD & Significance \\
\hline Efficiency & $\mathrm{X}$ & $\mathrm{X}$ & & 0.006 \\
Efficiency & $\mathrm{X}$ & & $\mathrm{X}$ & 0.000 \\
Outcomes & $\mathrm{X}$ & & $\mathrm{X}$ & 0.062 \\
Information & $\mathrm{X}$ & & $\mathrm{X}$ & 0.003 \\
$\begin{array}{l}\text { (question 11) } \\
\text { Information } \\
\text { (question 11) }\end{array}$ & & $\mathrm{X}$ & $\mathrm{X}$ & 0.000 \\
\hline
\end{tabular}

Note: $\mathrm{X}$ indicates where the significant differences are between age groups 
strength of the association for the sample, and for the sample as applies to the general population.

\section{Efficiency}

There were statistically significant differences between age groups regarding what percent of a charity's total spending should go towards charitable programs as opposed to overhead. Overhead was defined as the percentage spent on fundraising and administrative costs. Forty-two percent of young donors reported that 70 percent or less was an acceptable amount. Yet only 25 percent of baby boomers and 18 percent of mature donors felt that such a percentage was acceptable. Thirty-six percent of both baby boomers and mature donors believed that the percentage should be more than 80 percent. Only 25 percent of young donors held this belief. Clearly, young donors were less demanding regarding the amount charities should spend on overhead. Table 3 and Figure 3 demonstrate these significant differences. There were few responses for at least 50 percent and at least 60 percent (34 in total). Therefore, these answers were collapsed into 70 percent or less.
It was also less important for young donors to know the amount charities spent on overhead. Fifty-nine percent of young donors, 69 percent of baby boomers, and 73 percent of mature donors reported that it was very important to extremely important for them to know this percentage. These results were almost statistically significant and are displayed in Table 4.

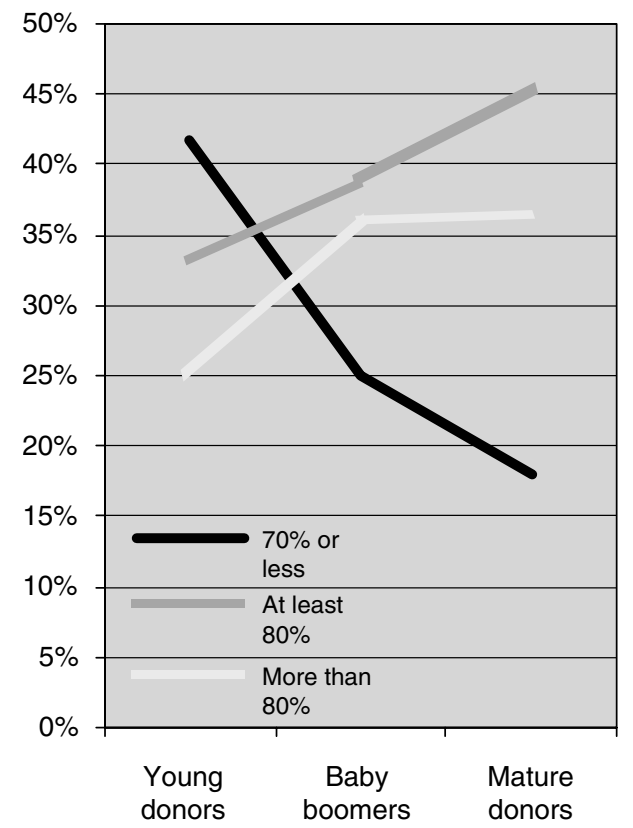

Figure 3: The percentage that should be spent on program activities

Table 3: Percent of spending that should go towards programs

\begin{tabular}{lllll}
\hline & $\begin{array}{l}\text { Young donors } \\
(\mathbf{\%})\end{array}$ & $\begin{array}{l}\text { Baby boomers } \\
(\mathbf{\%})\end{array}$ & $\begin{array}{l}\text { Mature donors } \\
(\mathbf{\%})\end{array}$ & Significance \\
\hline $70 \%$ or less & 41.7 & 25.0 & 17.9 & \\
At least $80 \%$ & 33.3 & 38.8 & 45.5 & \\
More than $80 \%$ & 25.0 & 36.2 & 36.6 & Pearson chi-square: 0.001 \\
& & & & Gamma: 0.010 \\
\hline
\end{tabular}


Table 4: How important it is to know the percentage spent on programs

\begin{tabular}{lllll}
\hline & $\begin{array}{l}\text { Young donors } \\
(\%)\end{array}$ & $\begin{array}{l}\text { Baby boomers } \\
(\%)\end{array}$ & $\begin{array}{l}\text { Mature donors } \\
(\mathbf{\%})\end{array}$ & Significance \\
\hline $\begin{array}{l}\text { Not important to important } \\
\begin{array}{l}\text { Very important to extremely } \\
\text { important }\end{array}\end{array}$ & 59.0 & 31.1 & 26.9 & $\begin{array}{l}\text { Pearson } \\
\text { chi-square: } 0.071\end{array}$ \\
& & 68.9 & 73.1 & Gamma: 0.044 \\
\hline
\end{tabular}

Table 5: How likely to give to a charity that spent a high percentage on overhead

\begin{tabular}{lclll}
\hline & $\begin{array}{l}\text { Young donors } \\
(\%)\end{array}$ & $\begin{array}{l}\text { Baby boomers } \\
(\mathbf{\%})\end{array}$ & $\begin{array}{l}\text { Mature donors } \\
(\mathbf{\%})\end{array}$ & Significance \\
\hline Never & 1.6 & 13.4 & 20.8 & \\
Rarely & 52.5 & 49.7 & 52.9 & \\
Sometimes to often & 45.9 & 36.9 & 26.3 & Pearson chi-square: 0.000 \\
& & & & Gamma: 0.000 \\
\hline
\end{tabular}

Young donors were more likely than baby boomers and mature donors to give to a charity that spent a high percentage on overhead. Forty-six percent of young donors reported they would sometimes to often give to such a charity. Only 37 and 26 percent of baby boomers and mature donors, respectively, would do so. These results were statistically significant and are displayed in Table 5 and Figure 4.

\section{Outcomes}

Although young donors were the least demanding group concerning organizational efficiency, they were the most likely to read information about an organization's accomplishments, such as program outcomes.

Interestingly, baby boomers were the least likely age group to read such information. Seventy-five percent of

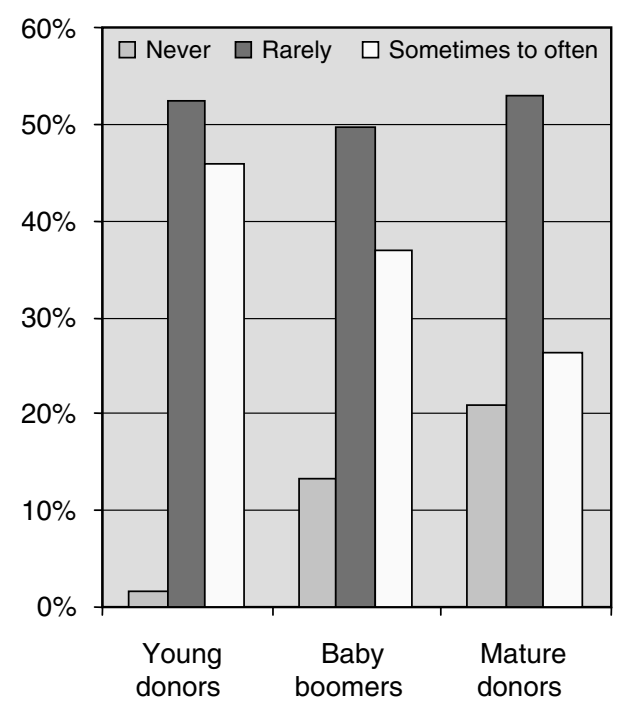

Figure 4: The likelihood of giving to a charity that spent a high percentage on overhead

young donors read information about accomplishments often to always, followed closely behind by mature 
Table 6: How often donors read information about program accomplishments

\begin{tabular}{lllll}
\hline & $\begin{array}{l}\text { Young donors } \\
(\mathbf{\%})\end{array}$ & $\begin{array}{l}\text { Baby boomers } \\
(\mathbf{\%})\end{array}$ & $\begin{array}{l}\text { Mature donors } \\
(\mathbf{\%})\end{array}$ & Significance \\
\hline Never to sometimes & 24.6 & 32.8 & 25.4 & \\
Often & 63.9 & 50.3 & 54.2 & \\
Always & 11.5 & 16.9 & 19.8 & Pearson chi-square: 0.101 \\
& & & & Gamma: 0.005 \\
\hline
\end{tabular}

Table 7: How often donors want information about program accomplishments

\begin{tabular}{lllll}
\hline & $\begin{array}{l}\text { Young donors } \\
(\mathbf{\%})\end{array}$ & $\begin{array}{l}\text { Baby boomers } \\
(\mathbf{\%})\end{array}$ & $\begin{array}{l}\text { Mature donors } \\
(\mathbf{\%})\end{array}$ & Significance \\
\hline $\begin{array}{l}\text { Never to once a year } \\
\begin{array}{l}\text { Two to more than } \\
\text { four times a year }\end{array}\end{array}$ & 63.6 & 32.8 & 25.4 & \\
& & 50.3 & 54.2 & Pearson chi-square: 0.011 \\
& & & Gamma: 0.062 \\
\hline
\end{tabular}

Table 8: Effect of knowing how a gift will be used

\begin{tabular}{|c|c|c|c|c|}
\hline & $\begin{array}{l}\text { Young donors } \\
(\%)\end{array}$ & $\begin{array}{l}\text { Baby boomers } \\
(\%)\end{array}$ & $\begin{array}{l}\text { Mature donors } \\
(\%)\end{array}$ & Significance \\
\hline No to likely & 32.8 & 51.0 & 54.7 & \\
\hline \multirow{2}{*}{$\begin{array}{l}\text { Most likely to } \\
\text { definitely }\end{array}$} & 67.2 & 49.0 & 45.3 & \\
\hline & & & & $\begin{array}{l}\text { Pearson chi-square: } \\
0.007 \\
\text { Gamma: } 0.015\end{array}$ \\
\hline
\end{tabular}

donors (74 percent). Only 67 percent of baby boomers read this information often to always. Additionally, young donors wanted information about accomplishments more often; their scores were again followed by mature donors and baby boomers. These results were almost statistically significant and can be seen in Tables 6 and 7 , respectively.
There was a dramatic difference between young and mature donors concerning their inclination to give more money to a charity if they had more information regarding how their gift would be used. Sixty-seven percent of young donors reported that they would most likely to definitely give a charity more money if they had more information on how their gift would 
be used. Only 49 and 45 percent of baby boomers and mature donors,

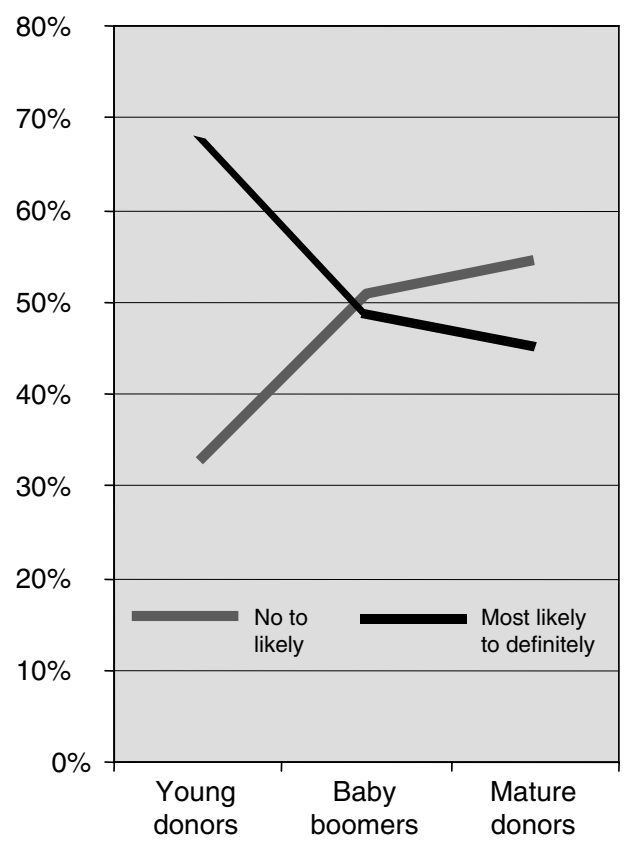

Figure 5: The effect of knowing how a gift will be used when making a decision to give respectively, would do so. These results were statistically significant and can be seen in Table 8 and Figure 5.

\section{Information}

Not surprisingly, there were compelling differences among young donors, baby boomers, and mature donors regarding their use of the internet and a charity's website. When making a decision to give, 72 percent of young donors used the internet and 74 percent used a charity's website to look for information about a charity. Mature donors were the least likely group to use the internet or a website. Fortyeight percent of mature donors used the internet, and 26 percent of mature donors used a charity's website to find information. These results were statistically significant and are displayed in Tables 9 and 10 and Figure 6.

Lastly, young donors used more sources for information; their mean score was three. Baby boomers used

Table 9: Look for information on a charity using the internet

\begin{tabular}{|c|c|c|c|c|}
\hline & $\begin{array}{l}\text { Young donors } \\
(\%)\end{array}$ & $\begin{array}{l}\text { Baby boomers } \\
(\%)\end{array}$ & $\begin{array}{l}\text { Mature donors } \\
(\%)\end{array}$ & Significance \\
\hline Yes & 72.1 & 65.4 & 48.4 & \\
\hline \multirow[t]{2}{*}{ No } & 27.9 & 34.6 & 70.1 & \\
\hline & & & & $\begin{array}{l}\text { Pearson chi-square: } 0.000 \\
\text { Gamma: } 0.000\end{array}$ \\
\hline
\end{tabular}

Table 10: Look for information on a charity using the charity's website

\begin{tabular}{|c|c|c|c|c|}
\hline & $\begin{array}{l}\text { Young donors } \\
(\%)\end{array}$ & $\begin{array}{l}\text { Baby boomers } \\
(\%)\end{array}$ & $\begin{array}{l}\text { Mature donors } \\
(\%)\end{array}$ & Significance \\
\hline Yes & 73.8 & 54.0 & 25.8 & \\
\hline \multirow[t]{2}{*}{ No } & 26.2 & 46.0 & 74.2 & \\
\hline & & & & $\begin{array}{l}\text { Pearson chi-square: } 0.000 \\
\text { Gamma: } 0.000\end{array}$ \\
\hline
\end{tabular}




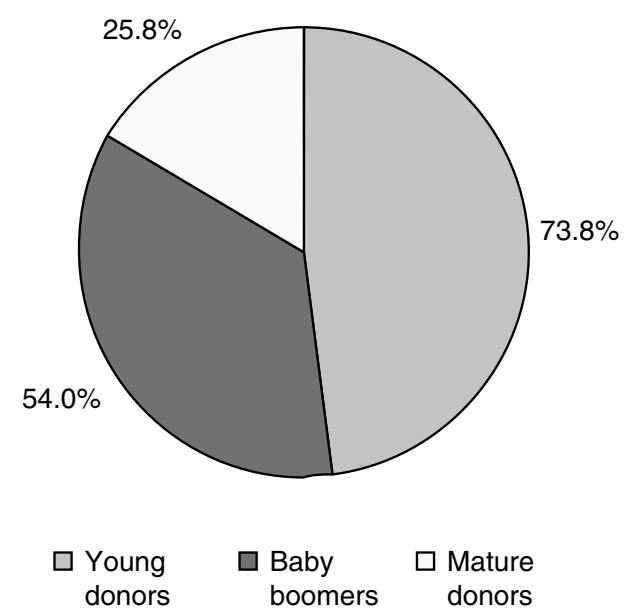

Figure 6: Those that looked for information using a charity's website

an average of 2.86 sources and mature donors used an average of 2.5 sources. These differences were significant at the 0.000 level.

\section{Additional findings}

Overall, a high percentage of donors are concerned about overhead, value program achievements, and actively seek information about a charity when making a decision to give. Eighty-six percent of donors responded that it was important to extremely important to have a universal "Seal of Approval" to identify charities that spent less on overhead and more on charitable programs. Additionally, 85 percent of donors reported that it was important to extremely important to have independent organizations that monitor how charities spend their money. When making a decision to give, knowing about a charity's recent achievements is important to extremely important to 81 percent of donors.

\section{Summary Statement}

There is a dearth of research in the current literature regarding the factors that affect giving in the baby boomer generation. In fact, most of what we know about baby boomers and their preferences is derived from the marketing literature and anecdotal evidence. Moreover, few (if any) researchers are looking into the importance of organizational outcomes, efficiency, and information on donors in different age groups. This research contributes needed information to the field on:

- the kinds of factors that donors consider when making a charitable gift;

- how organizational efficiency, outcomes, and information affect charitable giving; and

- the differences that may exist between donors of different age groups.

\section{Implications for the literature} The research corresponds with the existing literature by demonstrating that a majority of donors are concerned about organizational efficiency and outcomes, and that they desire this information from charities. The study also concurs with the existing literature by demonstrating that young donors use the internet to find information on a charity more than baby boomers and mature donors.

The study extends the existing literature on donor preferences and charitable giving by demonstrating that there are differences between age groups regarding the variables efficiency, outcomes, and information. Specifically, the research showed that the strongest differences lie between 
young donors and mature donors regarding organizational efficiency and program outcomes, and that there are significant differences between all age groups regarding their desire for information.

\section{Implications for the profession}

These findings have implications for the nonprofit sector and fundraising professionals. As the 990 form becomes more ubiquitous and is used by more foundations and watchdog organizations, the pressure for organizations to have low efficiency ratings will increase. At the same time, demands in the external environment are forcing the cost of management (and thus administrative costs) up, not down. For example, investing in fundraising capacity, purchasing and maintaining new technology, and paying certain insurances for employees and volunteers equates to a rise in the cost of doing business. The value of good management, however, should not be devalued by minimizing realistic overhead costs. Therefore, fundraisers may want to work on educating their donors, especially donors of the baby boomer and mature generations, about what efficiency really means and the negative impact that an efficiency rating that is too low can have on organizational effectiveness.

Fundraisers may want to consider segmenting their donor database by age and sending targeted messages to donors of different age groups. For example, fundraisers may wish to include information about organizational efficiency in appeals to mature donors, and include information about program outcomes in appeals to young donors.

Fundraisers may find that mailing mature donors less frequently and young donors more frequently has a positive effect on revenue. Fundraisers may also wish to offer more information on how gifts are being used, especially to young donors. Because of donors' reported desire for a "Seal of Approval," charities may wish to share any positive ratings or approvals from watchdog organizations with their membership.

This research showed that newsletters, program information updates, and websites are most likely to be read by young donors, with baby boomers following. Fundraisers may choose to craft these materials with such populations in mind. Because there is variation concerning how often donors want information from charities, fundraisers may wish to provide methods that allow donors to easily communicate their preferences to charities. Such actions could serve to increase the level of service provided to donors and save organizational resources.

\section{Implications for public policy}

This research also has implications for public policy. The passage of additional legislation, which may provide new controls concerning the audit process, contracts with professional fundraisers, and compensation for chief financial and executive officers, may help prevent scandals in the nonprofit sector. The cost of compliance, however, may also increase overhead and decrease the efficiency rating of many charities. This should be monitored, and the government may need to revisit their requirements for efficiency ratings 
regarding their grant making activities. The government, as well as watchdog agencies, may also choose to be more active in educating foundations and individuals about efficiency ratings.

\section{Recommendations}

Should this research be replicated, the author would recommend including a qualitative analysis for a random sample of donors. Such in-person interviews may help confirm or refute the findings from this research. The author would also recommend including more questions for the three variables. The reliability coefficients for efficiency, outcomes, and information were $0.557,0.565$, and 0.539 , respectively. These coefficients could be improved via the incorporation of additional questions and by testing the improved survey on a sample population.

\section{Conclusion}

As the nonprofit sector continues to grow and morph, nonprofits will need to have a solid understanding of their donor base, be aware of donor preferences, and be aware of the differences between donors. This information is essential for effective donor cultivation, solicitation, and stewardship. This study confirmed that a majority of donors value organizational efficiency and outcomes and that most donors seek information when making a decision to give. It also revealed significant differences between age groups that may help fundraisers and policy makers improve their understanding of donor preferences and charitable giving.

\section{Notes}

${ }^{1}$ Data was collected in 2004.

${ }^{2}$ The mean gift for these major donors was \$2.27 million.

\section{References}

Anthony, R.N. (1983), Tell It Like It Was: A Conceptual Framework for Financial Accounting, Richard D. Irwin, Inc, Homewood, IL.

Cherny, J., Gordon, A.R. and Herson, J.L. (1992), Accounting-A Social Institution: A Unified Theory for the Measurement of the Profit and Nonprofit Sectors, Quorum Books, New York, NY.

Cunningham, K. and Ricks, M. (2004, Summer), "Why measure: Nonprofits use metrics to show that they are Efficient. But what if donors don't care?," Retrieved August 11, 2004, from the Stanford Social Innovation Review Website: http://www.ssireview.com/articles.

Drtina, R.E. (1984), "Measurement preconditions for assessing nonprofit performance: An exploratory study," The Government Accountants Journal, 33, 2, pp. 13-19.

Hall, M.H. and Febbraro, A.R. (1999, Summer), "The public's concerns about fundraising and the use of donated dollars," Canadian Centre for Philanthropy: Research Bulletin, 6, 3. Retrieved June 24, 2004, from Canadian Centre for Philanthropy Website: http://www.ccp. ca/bulletins/rb99.htm.

Hall, M., Goulbourne, M. and McKeown, L. (2001, Summer), "Changing donation patterns: A warning for charitable organizations," Canadian Centre for Philanthropy: Research Bulletin, 8, 3. Retrieved June 24, 2004, from Canadian Centre for Philanthropy Website: http://www.ccp.ca/bulletins/rb106.htm.

Hall, M.H., Knighton, T., Reed, P., Brussière, P., McRae, D. and Bowen, P. (1998), "Caring Canadians, involved Canadians: Highlights from the 1997 national survey of giving, volunteering and participating," Retrieved June 26, 2004, from Canadian Centre for Philanthropy Website: http://www. givingandvolunteering.ca/reports/1997_NSGVP_ highlights.asp.

Hall, M.H. and Parmegiani, M. (1998, Summer), "Public opinion and accountability in the charitable sector," Canadian Centre for Philanthropy: Research Bulletin, 5, 2. Retrieved June 24, 2004, from Canadian Centre for Philanthropy Website: http://www.ccp.ca/files/ researchbulletins/rb0502.pdf.

Hart, P.D. (1999), "Toward 2000 and beyond: Charitable and social change giving in the new millennium, part 1," Fund Rraising 
Management, 30, 3, pp. 28-30. Retrieved June 24, 2004, from InfoTrac database.

Haynes, L. (2004, February), "Baby boomers: Laura Haynes warns it's time to forget about youth culture and listen to the agenda-setting leadership generation-the 40-somethings," Brand Strategy, 179, 31. Retrieved June 24, 2004, from InfoTrac database.

Hyndman, N. (1991), "Contributions to charities: A comparison of their information needs and the perceptions of such by the providers of information," Financial Accountability and Management, 7, 2, pp. 69-82.

Khumawala, S.B. and Gordon, T.P. (1997), "Bridging the credibility of GAAP: Individual donors and the new accounting standards for nonprofit organizations," Accounting Horizons, 11, 3, pp. 45-68.

Maryland Association of Nonprofit Organizations (2002), "Protecting the trust: Revisiting public attitudes about charities in Maryland," Retrieved June 26, 2004, from Maryland Association of Nonprofit Organizations Website: http://www.marylandnonprofits.org/html/ explore/07_01ppt.shtml.

Nayyar, S. (2003, May 1), "The wealth transfer," American Demographics, 25, 4. Retrieved June 24, 2004, from InfoTrac database.

Nichols, J.E. (1989, May), "Targeting baby boomers for fundraising," Fund Raising
Management, 20, 3, pp. 30-33. Retrieved June 24, 2004, from InfoTrac database.

Nichols, J.E. (1996, July), "Revisiting the baby boomers at mid-life," Fund Raising Management, 27, 5, pp. 14-16. Retrieved June 24, 2004, from InfoTrac database.

Parsons, L.M. (2001), "The impact of financial information and voluntary disclosures on contributions to not-for-profit organizations A field-based experiment," Unpublished doctoral dissertation, Bauer College of Business, University of Houston.

Princeton Survey Research Associates, Inc (2001, September), "BBB Wise Giving Alliance donor expectations survey,” Retrieved June 24, 2004, from BBB Wise Giving Alliance Website: http:// www.give.org/news/surveyintro.asp.

Sargeant, A. and Lee, S. (2002), "Improving public trust in the voluntary sector: An empirical analysis," International Journal of Nonprofit and Voluntary Sector Marketing, 7, 1, pp. 68-84. Retrieved September 10, 2004, from ProQuest database.

Smith, W.J. and Clurman, A. (1997), Rocking the Ages. The Yankelovich Report on Generational Marketing, Harper Business, New York, NY.

Weiss, M.J. (2003, May 1), "Great expectations: Baby boomer wealth forecasts wilt," American Demographics, 25, 4. Retrieved June 24, 2004 , from InfoTrac database. 